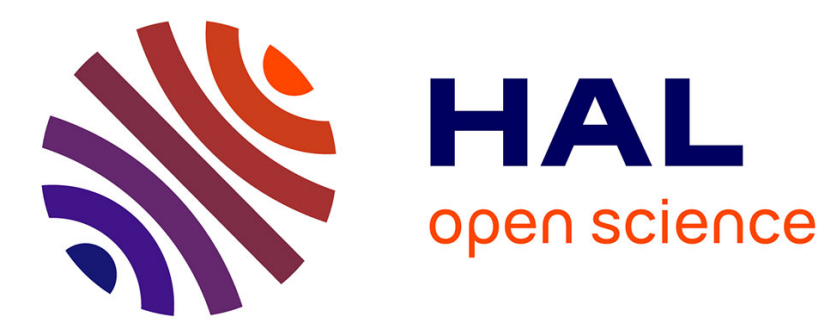

\title{
Near-field coupling between EMC filter components
}

Sanaa Zangui, Kévin Berger, Benjamin Vincent, Edith Clavel, Ronan

Perrussel, Christian Vollaire, Olivier Chadebec

\section{To cite this version:}

Sanaa Zangui, Kévin Berger, Benjamin Vincent, Edith Clavel, Ronan Perrussel, et al.. Near-field coupling between EMC filter components. IEEE CEFC, May 2010, Chicago, IL, United States. hal00485104

\section{HAL Id: hal-00485104 \\ https://hal.science/hal-00485104}

Submitted on 7 Dec 2010

HAL is a multi-disciplinary open access archive for the deposit and dissemination of scientific research documents, whether they are published or not. The documents may come from teaching and research institutions in France or abroad, or from public or private research centers.
L'archive ouverte pluridisciplinaire HAL, est destinée au dépôt et à la diffusion de documents scientifiques de niveau recherche, publiés ou non, émanant des établissements d'enseignement et de recherche français ou étrangers, des laboratoires publics ou privés. 


\title{
NEAR-FIELD COUPLING BETWEEN EMC FILTER COMPONENTS
}

\author{
S. Zangui*, K. Berger*, B. Vincent*, R. Perrussel*, E. Clavel**, C. Vollaire*, O. Chadebec** \\ $(*)$ : Laboratoire Ampère - CNRS UMR5005 - Université de Lyon, sanaa.zangui@ec-lyon.fr \\ (**) : Laboratoire G2Elab - CNRS UMR5269 - Grenoble Université, edith.clavel@g2elab.grenoble-inp.fr
}

\begin{abstract}
A method is proposed to compute the electromagnetic couplings between components in EMC filters. The technique is based on multipolar expansion, which provides a representation of generic structures. A simulation illustrates our approach by computing the mutual inductance between components according to their geometrical placement.
\end{abstract}

\section{INTRODUCTION}

Two types of parasitic parameters affect EMC filter performances: the well-known self-parasitic parameters and those due to couplings between the filter components. S. Wang et al. [1] have shown that these last parasitic parameters are the first to impact filter behavior as the frequency increases. Except by measuring, there is no way to know a priori (in the digital mockup) the performances of a filter while accounting for the near-field couplings between components. In this article, we propose a method based on multipolar expansion in order to compute these couplings. The multipolar equivalent model of the component allows us to compute efficiently any type of coupling in a wide range of frequency (up to $100 \mathrm{MHz}$ ) by providing a coarse representation of each element. In the present work, we expand on the different steps of our method, ending with a validation using the finite element method.

\section{Computing The Coupling MethoD}

A multipolar expansion allows us to represent the electromagnetic fields in 3D. This expansion is correct only for the example in Fig. 1 where the field is computed outside a reference sphere that contains the source. Our explanations focus on an example which deals with a magnetic coupling but a capacitive effect can also be inferred. Our method is composed of two steps.

\section{A. First step: identification of the multipolar components}

In the near-field area, the type of source is linked to the radial component of the same type of field (electric or magnetic). By collecting the radial component of the magnetic field $B_{r}$ on the validity sphere (radius $r_{V}$ ), it is possible to identify the equivalent magnetic multipolar component of the magnetic source:

$B_{r}(r, \theta, \varphi)=\frac{\mu_{0}}{4 \pi} \sum_{n=1}^{+\infty} \sum_{m=-n}^{+n} \frac{(n+1)}{r_{V}^{n+2}} A_{n m}^{B} S_{n m}(\theta, \varphi)$,

where $n$ is the order and $m$ the degree (there are $2 n+1$ degrees in order $n), r_{M}$, the distance to the center of the spherical coordinate system, $S_{n m}$, the real spherical harmonic functions, and $A_{n m}^{B}$, the unknown multipolar components to be identified. Depending on the complexity of the object being modeled, we can calculate the radiated $\mathbf{B}$-field by using a 3D numerical model of this object or by performing experimental measurements using sensors based on a multipolar representation [2].

\section{B. Second step: mutual inductance computation}

When the spheres which contain each of the sources do not intersect, the mutual inductance can be expressed according to the coefficients $A_{n m}^{B}$ of each source previously identified [3]:

$M_{12}(r, f)=\frac{1}{j 2 \pi f i_{1} i_{2} k^{2}} \sqrt{\frac{\varepsilon_{0}}{\mu_{0}}} \sum_{n=1}^{N_{\max }} \sum_{m=-n}^{+n}(-1)^{m}\left(A_{n m}^{B 1} \cdot A_{n m}^{B 2}(r)\right)$,

where $M_{12}$ is the mutual inductance between the sources 1 and $2, i$ denotes the current in each source and $f$, the frequency. The difficulty lies in the computation of the $A_{n m}^{B}$ components in the same coordinate system. For instance in (2), we have expressed the second source components in the first coordinate system, which is why $r$, the distance between the origins of the two coordinate systems, shown in Fig.1, is used to modify $A_{n m}^{B 2}$.

\section{First Results}

To validate our method, we computed the mutual inductance between two similar coils $C_{1}$ and $C_{2}$ (Fig.1) where $r$ is the distance between the centers of the coils (of radius Rcoil). In Fig.1, the mutual inductance computed using either Flux3D(C) software or our method (using a truncated multipolar expansion for $N_{\max }=3$ and $N_{\max }=5$ in (2)) are comparable.

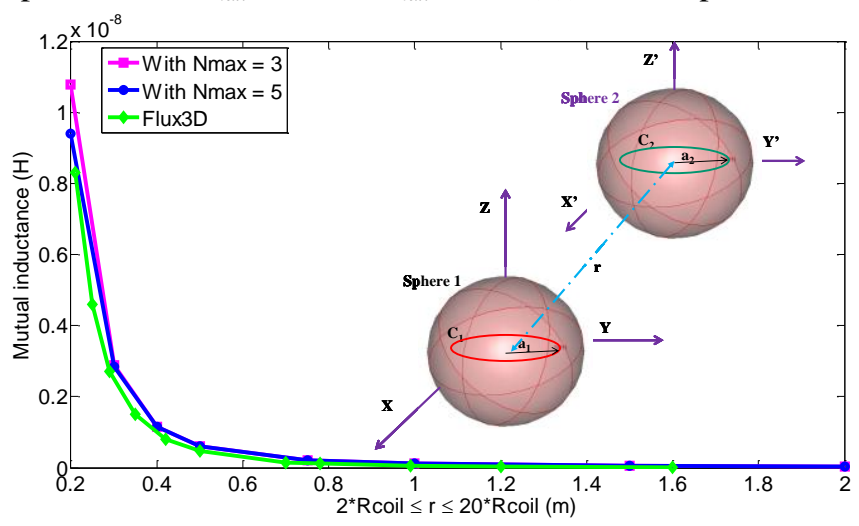

Fig.1. Results and source geometries

\section{REFERENCES}

[1] S. Wang et al., "Controlling the parasitic parameters to improve EMI filter performance," IEEE APEC, Vol.1, pp. 503-509, 2004.

[2] B. Vincent et al., "Loop antennas for Near Field Multipolar Expansion Identification: First experimental Validations," IEEE Transactions on Instrumentation and Measurement, Vol. 59 (12), pp. 3086-3092, 2010.

[3] Billy C. Brock, "Using vector spherical harmonics to compute antenna mutual impedance from measured or computed fields," SANDIA Report, SAND2000-2217-Revised. Sandia National Laboratories, Albuquerque, NM, 2001. 